\title{
NATIONAL CORRUPTION, NATIONAL PERSONALITY AND NATIONAL CULTURE
}

\author{
Brian S. Connelly \\ Deniz S. Ones ${ }^{1}$ \\ University of Minnesota
}

\begin{abstract}
Even though corruption continues to mar economic progression, worker enthusiasm, and societies' moral constitution, most studies of corruption have been confined to the fields of economics and political science. However, psychological variables, such as personality and cultural values, are likely to be relevant to studying corruption. In the present study of 62 countries, we examined how national averages on the Big Three personality traits, a measure of social desirability, and Hofstede's cultural dimensions relate to perceptions of a nation's level of corruption. The Big Three personality traits showed modest relationships with corruption. However, national averages on a social desirability measure were strongly and positively correlated with corruption, suggesting that national dishonesty in responding to personality items is related to national dishonesty in corruption. In addition, the discrete, combined, and unique effects of personality and culture on corruption were compared. The findings suggest that both cultural values and personality have relevance for understanding corruption. As globalization continues to promote the exchange of cultural values and the assimilation of both individuals and organizations into new cultures, these findings highlight the need for $1 / O$ psychologists to be attentive to both culture and personality in designing human resource systems.
\end{abstract}

Deşi corupția continuă să afecteze progresul economic, entuziasmul muncitorului şi standardele morale ale societății, cele mai multe studii asupra corupției au fost făcute în domeniul economic şi cel al ştiințelor politice. Cu toate acestea, este probabil ca variabilele psihologice, cum ar fi personalitatea şi valorile culturale, să fie relevante pentru studiul corupției. În prezentul studiu desfăşurat în 62 de țări, am cercetat modul în care indicatorii naționali medii în ceea ce priveşte trăsăturile de personalitate (Big Three), o măsură a dezirabilității sociale, şi dimensiunile culturale ale lui Hofstede sunt relaționate cu perceperea nivelului național de corupție. Modelul Big Three al trăsăturilor de personalitate a indicat o corelație modestă a trăsăturilor de personalitate cu corupția. În schimb, scorurile naționale medii în ceea ce priveşte măsura dezirabilității sociale au indicat o corelație puternică şi pozitivă cu corupția, sugerând că necinstea națională indicată de itemii de personalitate e relaționată cu necinstea națională implicată în corupție. În plus, au fost comparate efectele discrete, combinate şi unice ale variabilelor personalitate, respectiv cultură asupra corupției. Rezultatele sugerează că atât valorile culturale, cât şi factorii de personalitate au relevanță în ceea ce priveşte înțelegerea fenomenului de corupție. Câtă vreme globalizarea continuă să promoveze schimbul de valori culturale şi asimilarea atât a indivizilor, cât şi a organizațiilor în culturi noi, aceste rezultate evidențiază necesitatea ca psihologii M/O să fie atenți atât la factorii culturali, cât şi la cei de personalitate, în proiectarea sistemelor de resurse umane.

Key-words: corruption, cultural variables, psychological variables, Big Three

Whether it be government officials, corporate executives, military leaders, or even charitable organizations, the corruption of authority threatens the welfare of millions every year. Research on corruption has emerged in a wide variety of fields, including economics, political science, financial investments, sociology, psychology, law, and national

\footnotetext{
${ }^{1}$ Adresa de contact: conne122@umn.edu; onesx001@umn.edu
}

development, just to name a few. Interest in understanding corruption extends beyond simply ensuring that justice be served to those who are corrupt. With the world moving toward a more global economy in which investments, resources, and support are sent to locations further from the direct monitoring of their source individuals, organizations, and governments are increasingly focusing on the integrity of these transactions. Against this backdrop, many are desperate to understand 
why corruption happens and how it can be stopped.

Though multiple definitions exist, corruption researchers have generally defined corruption as "the misuse of public power for private benefit" (Goldsmith, 1999; Lambsdorff, 1995/2004; Xin \& Rudel, 2004). This definition includes a variety of nefarious behaviors such as embezzlement, bribery, and nepotism. A key component of this definition is "public power;" for individuals to be able to engage in corrupt behaviors, they have to have been entrusted to some degree with power or authority over others. However, this power and authority may come in many forms, and this definition is not intended to limit "the misuse of public power" specifically to misuse by those in government, or those in any other industry. This definition, however, excludes a number of other related but conceptually different acts, such as petty or violent theft (no public power is required for these acts) or political instability (misuse may not be evident, and it is unlikely to produce private benefits). Although multiple definitions of corruption exist in the literature and across cultures, many universal trends underlie corruption, such as the exploitation of power, selfish orientation of the corrupt actor, and the detrimental effects of corrupt acts on the society in which they occur (Akindele, 1995).

As noted above, research on corruption has adopted a variety of different perspectives, including economic, political, sociological, and psychological. In addition to the differences in the types of variables that are studied by each perspective, studies of corruption may also focus on corruption at different levels of analysis. For example, it is possible to conceptualize corruption at the individual level (what makes a single person more or less corrupt), at the organizational level (what makes an entire organization more or less corrupt), and at the national level (what makes countries more or less corrupt). Klein and colleagues (Klein et al., 2000; Klein, Dansereau, \& Hall, 1994) show that relationships between two variables at one level do not necessarily hold at other levels; other relationships may be stronger, weaker, or oppositely signed. For example, if men were shown to engage in more corrupt behaviors than women, this would not mean that organizations or countries with higher proportions of men in them would necessarily be more corrupt.
So far, most psychological studies of corruption have been limited to studying corruption at the individual level of analysis (usually under the title of white collar crime or certain types of counterproductive work behaviors). However, though they have been relatively limited in research on national corruption, psychological variables may also provide unique insights into understanding corruption at the national level. Specifically, the purpose of the present research is to explore the role that national personality may play in explaining national corruption. We first review existing literature that links personality to corrupt behaviors at the individual level. Then, we build upon this knowledge to explore ways in which personality traits at the national level may relate to national corruption. Finally, we consider the joint roles that national personality and national culture may play in explaining national corruption.

Personality and Corruption at the IndividualLevel of Analysis

In the past decade, personality has made a strong appearance in research in $\mathrm{I} / \mathrm{O}$ psychology on workplace deviance. However, considerable debate exists among personality theorists regarding the structure of the traits that make up personality. Much of the current research has focused on the Five Factor Model (Costa \& McCrae, 1992; Digman, 1990), which contains the traits neuroticism, extraversion, openness to experience, conscientiousness, and agreeableness. However, Eysenck (1970) argued that three personality factors constituted the core of personality: neuroticism, extraversion, and psychoticism. Eysenck's three traits are generally considered to align closely with the Five Factor Model, with neuroticism and extraversion being conceptualized similarly and with psychoticism representing a composite trait of conscientiousness and agreeableness (openness to experience is not clearly represented in this taxonomy; Bouchard \& Loehlin, 2001). Alternate perspectives exist delineating the number of factors constituting the structure of personality (Digman, 1997; D. N. Jackson, Paunonen, Fraboni, \& Goffin, 1996), but we focus here on the five and three factor models because of their centrality in previous research on corruption, because of their usefulness in organizing many subfacets of personality, and because of their relevance in the present study.

Personality's effects on corruption at the individual-level can be understood best by 
examining personality correlates of counterproductive work behaviors (CWBs) and white collar crime. Recent meta-analyses have linked CWBs to conscientiousness $(\rho=.26)$, agreeableness $(\rho=.20)$, and integrity, a composite trait of conscientiousness, emotional stability and agreeableness. $(\rho=.47$; Baehr, Jones, \& Nerad, 1993; Salgado, 2002). In a separate meta-analysis, Berry, Ones, and Sackett (2005) studied the relationship of the Big 5 traits with organizational deviance (CWBs that are harmful to the organization) and interpersonal deviance (CWBs that are harmful to other coworkers). Again, agreeableness and conscientiousness were strongly related to measures of CWBs; however, these correlations diverged slightly when comparing interpersonal versus organizational deviance. Conscientiousness correlated more strongly with organizational deviance $(\rho=-.42)$ than with interpersonal deviance ( $\rho=-.23$ ), whereas agreeableness correlated more strongly with interpersonal deviance $(\rho=-.46)$ than with organizational deviance ( $\rho=-.32$ ). In addition, emotional stability proved to be a moderate predictor of interpersonal and organizational deviance ( $\rho=$ -.24 and -.23 , respectively).

Note that the majority of these studies of CWBs have been conducted on samples at low- and mid-levels of the organization, rather than at more senior levels. However, CWBs at higher-levels of management (those positions in which individuals actually have adequate "public power" to engage in corrupt behavior) may be a slightly different construct. Some CWBs of high-level CWBs have direct analogs at lower levels (for example, embezzlement is very similar to theft), but other corrupt behaviors do not (e.g., bribery, extortion, insider-trading; H. L. Jackson, 2006). Thus, corrupt behaviors likely constitute a slightly different construct than counterproductive work behaviors that may have somewhat different antecedents.

Given the difficulty in obtaining access to the counterproductive behaviors of seniorlevel leaders in an organization, relatively little research has been conducted examining the antecedents of senior level-counterproductivity (see H. L. Jackson, 2006). The research most closely associated is a study by Collins and Schmidt (1993) on white collar crime. Collins and Schmidt (1993) compared the backgrounds (measured by a biodata questionnaire) and personality traits (measured by the California Psychological Inventory and an integrity test) of white collar crime convicts to a second sample of white collar employees. White collar offenders scored lower on integrity $(d=1.58)$, socialization $(d=1.02)$, responsibility $(d=.57)$, and tolerance $(d=.69)$ and higher on social extraversion $(d=-.58)$ and anxiety $(d=-.58)$ than their non-convict counterparts. Additionally, Baehr, Jones, and Nerad (1993) found internal locus of control and emotional health (two characteristics related to Big Five emotional stability) to be positively related to scores on a business ethics measure amongst a sample of uppermanagers. Within the framework of the Big Five, these studies suggest that white collar crime relates to low conscientiousness, and low emotional stability.

An additional stream of individual-level research related to corruption has focused on whistleblowers. Whereas white-collar crime is an individual-level behavior increasing national corruption, whistle-blowing is an individuallevel behavior likely to reduce national corruption. Near and Micelli (1996) reviewed research on whistleblowing and described whistleblowers as being moral/religious, having low tolerance for ambiguity, low self-esteem, and having an external locus of control. Miceli, van Scotter, Near, and Rehg (2001) proposed that whistleblowers will be high on positive affect, low on negative affect, and will have proactive dispositions. Within the Big Five framework, whistleblowing is likely to be associated with conscientiousness, extraversion, and agreeableness (the findings were inconsistent between whistleblowing and constructs related to emotional stability: negative affect, self-esteem, and locus of control; Judge, Locke, Durham, \& Kluger, 1998).

\section{Corruption at the National-Level}

A considerable amount of research has emerged in the past few years examining relationships between personality at the national level and other national-level variables. This work has aimed to administer personality measures to representative samples within a wide number of countries and has calculated national means on those traits. Considering the "personality of a nation" may seem counterintuitive because personality is generally conceptualized as an individual-level variable, but these national personality scores describe the national character of a country (McCrae, 2001). The measurement of national 
character describes not only the inhabitants within a country but also the type of culture that likely emerges from such inhabitants. For example, a country with a high extraversion score will likely have citizens who are more extraverted, but their culture is also likely be more sociable, have more festivals and celebrations, etc. Interestingly, research has shown that national stereotypes do not align closely at all with national personality scores, suggesting the two constructs are fairly distinct (Terracciano et al., 2005).

As noted above, existing research on national corruption has paid little research attention to psychological variables. One exception, however, is research examining the links between national corruption and national culture (which have been linked to national personality; see McCrae, 2001). Hofstede (1980; , 2001) defines culture as "the collective programming of the mind" and describes four different dimensions of culture. Individualism/ Collectivism (autonomy vs. assimilation with others), Masculinitiy/Femininity (valuing achievements and competition vs. caring and emotional attachments), Power Distance (the salience of social hierarchy and the degree of inequality) and Uncertainty Avoidance (the extent to which the unknown is seen as threatening). These four dimensions have been frequently studied in relation to other national characteristics. Husted (1999) examined the relationships between these cultural dimensions and national culture. Power distance was the strongest cultural predictor of corruption $(r=.72)$, perhaps because high power distance countries tend to reward loyalty rather than merit, making subordinates be less likely to challenge the corrupt practices of their superiors. Masculinity showed a modest correlation with corruption $(r$ $=.27$ ), consistent with claims that higher proportions of women in government reduce corruption (Dollar, Fisman, \& Gatti, 2001; Swamy, Knack, Lee, \& Azfar, 2001). Uncertainty avoidance showed a modest correlation with corruption $(r=.32)$. Collectivism also showed a strong associated with corruption $(r=.72)$; however, this relationship disappeared after controlling for wealth.

To our knowledge, only one study has presented correlations between national personality and national corruption (van Hemert, van de Vijver, Poortinga, \& Georgas, 2002). This study examined the relationships between national scores on the big three personality traits (extraversion, psychoticism, and neuroticism, as well as a social desirability scale) and over 30 different other national variables, of which national corruption was one. Van Hemert et al. (2002) found that extraversion, psychoticism, and neuroticism were very weakly related to corruption $(|r|<$ $.14)$, but the social desirability scale was very strongly related to national corruption $(r=.71)$.

Although these links between personality and national corruption are particularly weak, we believe the relationships between these personality traits and national corruption merits reexamination for several reasons. First, the scope of van Hemert et al.'s (2002) study afforded little attention to the theorizing about the relationships between these national personality and national corruption. As mentioned above, corruption was not the focus of this study at all, and its only treatment in the article was its tabled correlations and a few descriptive sentences. Second, van Hemert et al. (2002) culled their data on national personality scores from Lynn and Martin (1995), a source which has since been shown to have a number of inaccuracies in the scores reported based on the included samples (see Steel \& Ones, 2002 for a discussion of some problems associated with data from this source). Correcting these errors is necessary lest national personality be otherwise dismissed from the study of national corruption entirely based entirely on potentially erroneous data. Third, no research has yet examined the combined effects of personality, the unique effects of each personality trait (controlling for the other traits, as well as for important economic variables).

In addition, scholars of national cultural have begun debating about the roles of national personality and national culture in shaping the behavior of individuals. Hostede and McCrae (2004) jointly debate these discrepant perspectives. In this article, McCrae argues that nations differ in personality largely because of historical genetic differences and that these differences affect the personality and behavior of inhabitants of a nation, which in turn create the nation's culture. In contrast, Hofstede argues that the culture of a nation strongly affects the way that individuals interpret and respond to their environment, which in turn affects the development of personality within that nation. In light of this debate, it is important that studies of national personality also consider its role in tandem with national culture. Thus, a final purpose of 
the present study is to consider the joint roles of national personality and culture in predicting national corruption.

\section{Methods}

\section{Sample}

Given that our study focuses on corruption at the national level, we created a database consisting of data on 62 countries (see "Measures" section below for a description of this database and Table 1 for a listing of countries included in our database). Of these 62 countries, 8 were in North America (12.9\%), 8 were in South America (12.9\%), 22 were in Europe (35.5\%), 15 were in Asia $(24.2 \%), 4$ were from Africa $(6.5 \%), 3$ were from the Middle East (4.8\%), and 2 were from Australia (3.2\%). The Gross Domestic Product per capita (GDP per capita) for nations comprising our sample was .49 standard deviations above the mean GDP per capita for all nations, and the mean national population of our sample was .49 standard deviations above the mean national population for all nations. In addition, the standard deviation of GDP per capita was $22 \%$ larger in our sample, and the standard deviation of the national population was $86 \%$ larger than the standard deviation for the national populations of all countries. Thus, our sample may not be entirely representative of all the nations in world. However, when considering that less than 200 recognized countries (by most counts) constitute the population of nations in the world, 62 nations constitutes a large proportion of the available population of nations. In addition, this sample is similar in size to other studies examining psychological variables at the national-level (e.g., McCrae, 2001; Steel \& Ones, 2002; van Hemert et al., 2002).

Table 1. Countries in Our Database, Sample Sizes per Country, and Number of Corruption Perception Index (CPI) Ratings

\begin{tabular}{|c|c|c|c|c|}
\hline \multirow{2}{*}{ Country } & \multirow{2}{*}{$\begin{array}{l}\text { EPQ Sample } \\
\text { Size }\end{array}$} & \multicolumn{2}{|c|}{ Hofstede Sample Sizes } & \multirow{2}{*}{$\begin{array}{l}\text { \# CPI } \\
\text { Ratings }\end{array}$} \\
\hline & & Time 1 & Time 2 & \\
\hline Argentina & & 543 & 602 & 10 \\
\hline Australia & 654 & 805 & 1,114 & 10 \\
\hline Austria & & 586 & 661 & 9 \\
\hline Bangladesh & 1,075 & & & 4 \\
\hline Belgium & & 1,057 & 1,328 & 10 \\
\hline Brazil & 1,396 & 690 & 1,884 & 10 \\
\hline Bulgaria & 1,038 & & & 7 \\
\hline Canada & 1,257 & 715 & 2,861 & 10 \\
\hline Chile & & 164 & & 10 \\
\hline China & 1,000 & & & 9 \\
\hline Colombia & & 175 & 252 & 10 \\
\hline Costa Rica & & 164 & 30 & 8 \\
\hline Denmark & & 567 & 737 & 10 \\
\hline Ecuador & & 172 & 36 & 7 \\
\hline Egypt & 1,330 & & & 7 \\
\hline El Salvador & & 171 & 37 & 7 \\
\hline Finland & 949 & 377 & 425 & 10 \\
\hline France & 811 & 4,691 & 6,646 & 10 \\
\hline Germany & 1,336 & 3,477 & 7,907 & 10 \\
\hline Greece & 1,301 & 111 & 127 & 10 \\
\hline Guatemala & & 153 & 23 & 6 \\
\hline Hong Kong & 732 & & 88 & 9 \\
\hline
\end{tabular}


Table 1 (continued)

\begin{tabular}{|c|c|c|c|c|}
\hline \multirow{2}{*}{ Country } & \multirow{2}{*}{$\begin{array}{l}\text { EPQ Sample } \\
\text { Size }\end{array}$} & \multicolumn{2}{|c|}{ Hofstede Sample Sizes } & \multirow{2}{*}{$\begin{array}{l}\text { \# CPI } \\
\text { Ratings }\end{array}$} \\
\hline & & Time 1 & Time 2 & \\
\hline Hungary & 962 & & & 10 \\
\hline Iceland & 1,144 & & & 7 \\
\hline India & 981 & 231 & & 10 \\
\hline Indonesia & & 186 & 28 & 10 \\
\hline Iran & 624 & 115 & 116 & 2 \\
\hline Ireland & & 119 & 132 & 10 \\
\hline Israel & 1,050 & 142 & 215 & 9 \\
\hline Italy & 802 & 1,797 & & 10 \\
\hline Jamaica & & 181 & 24 & 5 \\
\hline Japan & 1,318 & 2,345 & 4,103 & 10 \\
\hline Lithuania & 1,404 & & & 6 \\
\hline Malaysia & & 175 & 27 & 10 \\
\hline Mexico & 988 & 498 & 518 & 10 \\
\hline Netherlands & 876 & 593 & 1,204 & 10 \\
\hline New Zealand & & 173 & 240 & 10 \\
\hline Nigeria & 430 & & & 9 \\
\hline Norway & 802 & 360 & 459 & 10 \\
\hline Pakistan & & 37 & 70 & 9 \\
\hline Panama & & 152 & 26 & 4 \\
\hline Peru & & 138 & 152 & 7 \\
\hline Philippines & & 158 & 161 & 10 \\
\hline Portugal & 1,163 & & 243 & 10 \\
\hline Romania & 1,014 & & & 8 \\
\hline Russia & 1,067 & & & 9 \\
\hline Singapore & 785 & & 58 & 10 \\
\hline South Africa & & 349 & 518 & 10 \\
\hline South Korea & 1,200 & 209 & 30 & 10 \\
\hline Spain & 994 & 600 & 1,202 & 10 \\
\hline Sri Lanka & 1,030 & & & 3 \\
\hline Sweden & & 1,128 & 1,304 & 9 \\
\hline Switzerland & & 951 & 1,160 & 10 \\
\hline Taiwan & 1,027 & & 71 & 10 \\
\hline Thailand & & 80 & & 10 \\
\hline Turkey & & 106 & 62 & 10 \\
\hline Uganda & 1,476 & & & 7 \\
\hline United Kingdom & 1,476 & 3,236 & 3,731 & 10 \\
\hline United States & 1,198 & 3,967 & & 10 \\
\hline Uruguay & & 175 & 27 & 7 \\
\hline Venezuela & & 217 & 318 & 10 \\
\hline Yugoslavia & 971 & & 248 & 3 \\
\hline
\end{tabular}

Note. Empty cells indicate measures for which data was not available. 


\section{Measures}

Corruption Perceptions Index (CPI). To measure national corruption for each country, we created a composite index pooled from yearly scores on the Corruption Perceptions Index. The CPI is a yearly report published by Transparency International that rates nations on the extent of "the misuse of public power for private benefit" (Lambsdorff, 1995/2004). The $\mathrm{CPI}$ is regularly used by researchers and practitioners in economics, international politics, and international finance, and has been cited in over 70 journal articles (e.g., Habib \& Zurawicki, 2002; Jain, 2001; Johnson, Kaufmann, \& Zoido-Lobaton, 1998).

The CPI is labeled as a "survey of surveys;" that is, the ratings it presents are calculated by combining responses to surveys on corruption from a variety of different sources. For a survey to be included in a year's CPI rating, it must (a) sample across multiple countries, (b) contain some measure of global corruption within the country, and (c) have been conducted within the previous three years of a given CPI rating (e.g., the 2002 ratings for the $\mathrm{CPI}$ contained only surveys conducted between 2000 and 2002). Such surveys are usually conducted by large financial investors (e.g., the World Bank), but they are also conducted by advocacy groups and other Non-Governmental Organizations. Between 1995 and 2004, the CPI has included 71 administrations of 26 different surveys conducted by 21 different organizations. These 71 administrations of the surveys included between 11 and 155 countries, with a mean of $61.90(\mathrm{SD}=46.29)$. These surveys have typically sampled managers, political and economic experts, expatriates, and the general public. Thus, the CPI represents a broad sampling of individuals and of methods of measuring corruption. Despite this breadth in sampling, the surveys show strong consistency: the 759 available intercorrelations of surveys have a mean correlation of $r=.81$ $(S D=.14)$. The Appendix lists the sources and surveys included in the $\mathrm{CPI}$, as well other information regarding the samples used and questions asked in these surveys.

How the surveys are combined into the $\mathrm{CPI}$ has evolved through three different procedures. Initially, in the first procedure (1995-2000), survey results for each country were simply standardized (converted to zscores) and averaged. However, Lambsdorff (2001) point out that many of these surveys do not contain a random sample of countries. For example, a survey may focus specifically on the world's 20 most corrupt countries. If a survey sampling in such a way was included in the CPI, this survey would upwardly bias the CPI scores for most of these countries (i.e., approximately half of the countries would receive positive z-scores, whereas their truescore is well below the mean). Thus, the second procedure (2001) refined the procedure such that z-scores of the current survey results were used to adjust the country's previous year's CPI score. However, Lambsdorff (2002) show that such a procedure would continually constrain the variance in CPI scores. Thus, the third procedure (2002-2004) was introduced and used a matching percentiles technique. In this procedure, countries are ranked according the previous year's CPI results. To create a new year's CPI scores, countries sampled in a given survey are ranked according to the survey results. Based on these survey rankings, countries are matched to the rankings of the previous year's $\mathrm{CPI}$ and are assigned a corresponding score (for example, if a country was ranked $8^{\text {th }}$ in a survey sampling 35 countries, that country would be assigned the previous year's CPI score of the $8^{\text {th }}$ highest country out of those 35). Such matching continues to convert scores for all surveys, and those scores are then averaged across all surveys.

Of the ten years for which the CPI has been computed, there are strong intercorrelations across years $(M=.97, S D=$ .02 ), even for years without overlapping surveys computed using the first procedure $(r$ $>$.94). In order to both maximize our sample and to create a more stable estimate of a country's corruption, we created a composite overall CPI score that averaged all ten years of the CPI's scores $(\square=.997)$. This produced scores for 144 countries, 62 of which matched countries in our database. Finally, although high scores on the CPI typically represent lack of corruption in a country, we have reversed the signs of correlations and betas such that a positive correlation indicates that a variable is associated positively with corruption.

\section{Eysenck Personality Questionnaire}

To measure national personality, we used national means on the Eysenck Personality Questionnaire (EPQ). The EPQ is a commonly-used instrument designed around the three factor model of personality and measures three corresponding personality traits: Extraversion $(\mathrm{E})$, Psychoticism $(\mathrm{P})$, and Neuroticism ( $N$ ). In addition, the instrument 
includes a measure of social desirability, the Lie (L) scale. The EPQ scales have shown internal consistencies between $\square=.78$ and $\square$ $=.90(\mathrm{H}$. Eysenck, 1991), suggesting the instrument to have highly reliable scales. The $E P Q$ was originally developed in Great Britain, but it has been translated into ___ languages. Despite this large number of translations, several studies have confirmed that the instrument retains its factor structure when administered in different languages and to different cultures (P. Barrett \& Eysenck, 1984; P. T. Barrett, Petrides, Eysenck, \& Eysenck, 1998).

We obtained national-level data from Steel and Ones (2002), who made a number of corrections to data originally presented in Barrett and Eysenck (1984) and Lynn and Martin (1997). This data compiled national mean scores on $E, P, N$, and $L$ scales based on national representative samples. This data was available for 39 nations for $E, P$, and $N$ and for 24 nations for the $L$ scale and was gathered between 1975 and 1998. Each country sampled 1,059 participants on average, with a range between 430 and 1912 . This national level mean scores have also shown strong convergent validity and discriminant validity with national means on the NEO-PI-R (McCrae, 2001).

Hofstede's Cultural Dimensions. To measure national culture, we used Hofstede's dimensions of national culture (Hofstede, 1980, 2001). Hofstede administered a measure of attitudes and values to 117,000 IBM employees in 72 countries. These employees spanned a variety of job classes, such as managers, sales representatives, and technicians. In administering the survey to employees, the survey was translated into 20 different languages. These translations were reviewed by bilingual reviewers to ensure equivalency.

Hofstede (2001) factor analyzed national level mean scores for the 50 countries providing the largest samples. This analysis revealed four dimensions: individualism/ collectivism, power distance, uncertainty avoidance, and masculinity/femininity. Scores on these dimensions for each of the 50 countries are provided in Hofstede (2001). Since first developed and released in 1980, these national level mean cultural scores have been used in a wealth of research, and Hofstede (2001) presents correlations of other national level variables with these cultural dimensions from over 120 other sources. In addition, these national level mean scores have shown adequate test-retest reliability: a subset of the original 72 countries were surveyed twice within a four-year period. The mean scores of these countries showed strong consistency between administrations (Hofstede, 1980). On the whole, over 25 years of research have supported the reliability and validity of these scores.

Wealth. To measure national wealth, data on the Gross Domestic Product (GDP) per capita was culled from the statistics division of the $U$. N. (U.N. Statistics Division, 2005) for each country in our database. Gross domestic product is an estimate of the total value of all goods and services produced within a country per person for a given year. We calculated the average GDP per capita for each country from the period between 1990 and 1999, a period roughly concurrent with the time in which data was collected for the CPI and EPQ.

\section{Results}

To begin, means, standard deviations, and intercorrelations were calculated for all variables in our database. These statistics are presented in Table 2. In examining the correlations of personality variables with corruption, Psychoticism $(r=.21)$ and the Lie scale $(r=.57)$ were the strongest single personality predictors. This indicates that countries that are more Psychotic and have higher social desirability scores tend to also have more corruption. Several cultural variables also showed strong correlations with national corruption, specifically Individualism/ Collectivism ( $r=-.72)$, Power Distance $(r=$ $.69)$, and Uncertainty Avoidance $(r=.41)$. This indicates that countries that are high in Power Distance and Uncertainty Avoidance but low in Individualism tend to be the most corrupt. Finally, national wealth was the strongest zeroorder predictor of national corruption $(r=-.87)$. This finding suggests that poorer nations tend to have more corruption.

Next, we examined the combined ability of these psychological variables to predict corruption by computing several multiple regression models. These regression models are presented in Table 3 . In Model 1, all four personality variables were entered simultaneously, producing a multiple- $R_{a d j}$ of $R_{a d j}=.50(N=36)$. This suggests that national 
Table 2. Country-level Means, Standard Deviations, and Intercorrelations for Personality, Culture, Wealth, and Corruption

\begin{tabular}{|c|c|c|c|c|c|c|c|c|c|c|c|c|}
\hline & Mean & SD & $E$ & $\mathrm{P}$ & $\mathrm{N}$ & $\mathrm{L}$ & $\mathrm{I} / \mathrm{C}$ & $\mathrm{M} / \mathrm{F}$ & PD & UA & Wealth & Corrup \\
\hline Extraversion & 18.26 & 2.29 & 36 & & & & & & & & & \\
\hline Psychoticism & 4.67 & 1.46 & -.15 & 36 & & & & & & & & \\
\hline Neuroticism & 14.37 & 2.17 & -.30 & .31 & 36 & & & & & & & \\
\hline Lie Scale & 15.24 & 3.97 & .16 & -.18 & -.23 & 24 & & & & & & \\
\hline Individualism & 43.94 & 25.85 & .30 & -.24 & -.15 & -.38 & 50 & & & & & \\
\hline Masculinity & 48.86 & 18.83 & .20 & .27 & .46 & -.56 & .07 & 50 & & & & \\
\hline Power Distance & 55.98 & 21.98 & -.12 & .38 & .51 & .39 & -.67 & .06 & 50 & & & \\
\hline Uncert. Avoid. & 65.90 & 24.92 & .02 & -.11 & .34 & .07 & -.35 & -.03 & .24 & 50 & & \\
\hline Wealth* & 10.78 & 10.96 & -.06 & -.15 & -.09 & -.68 & .73 & .00 & -.62 & -.27 & 62 & \\
\hline Corruption & 5.23 & 2.54 & .09 & .21 & .15 & .57 & -.72 & .15 & .69 & .41 & -.87 & 62 \\
\hline
\end{tabular}

Note. Boldfaced correlations have $90 \%$ confidence intervals that do not include zero. Ns are presented in the diagonal and range from 15 to 62 for each cell.

${ }^{*}$ Means and standard deviations are presented in thousands of dollars

personality is generally a very strong predictor of national corruption. In particular, examining the $\square$ coefficients suggests that this prediction was driven primarily by Psychoticism $(\square=.23)$ and the Lie scale $(\square=.61)$, which was consistent with the zero-order correlations. Next, we examined the combined ability of national culture in predicting corruption. In Model 2, corruption was simultaneously regressed on all four cultural dimensions. This produced a multiple- $R_{a d j}$ of $R_{a d j}=.78(N=50)$, suggesting that national culture is strongly linked to national corruption. The $\square$ coefficients suggest that corruption is most strongly predicted by Individualism ( $\square=-.44$ ) and Power Distance $(\square=.35)$. This suggests also that the relationship between Uncertainty Avoidance and corruption becomes considerably diminished once the other cultural variables are accounted for.

Next, we compared the effectiveness of national personality and national culture in predicting corruption. Because these analyses were conducted using a moderately large number of predictors on a somewhat small sample $(N=15)$, we caution strongly against interpreting the $\square$-coefficients presented in these models. However, the sample size limitations do not as drastically affect interpretations of multiple- $R_{a d j}$ values (Cohen, West, Aiken, \& Cohen, 2002), which we focus on here. In Model 3, culture was first regressed on all four personality variables in Step 1, and the four cultural variables were added in Step 2. This suggested that adding national culture to national personality produced a change in multiple- $R_{a d j}$ of $\square R_{a d j}=.05$. In Model 4, corruption was regressed on national culture in Step 1, and national personality was added in Step 2. This showed that adding personality to national culture produced a change in multiple$R_{a d j}$ of $\square R_{a d j}=.09$. Thus, although the $R_{a d j}$ value in Model 2 of national culture alone was greater than the $R_{a d j}$ value in Model 1 of national personality, national personality provided a greater increment over national culture for predicting national corruption.

Finally, because national wealth was such a strong predictor of national corruption, we reran regression Models 1 and 2 with national wealth entered as a control variable. This data is presented in Table 4. When the four personality variables are added to wealth in predicting national corruption (Model 5), the multiple- $R_{a d j}$ value actually decreased from $R_{a d j}=.75$ to .72 . This finding suggests that effects of national personality on national culture may be fully mediated by national wealth. In model 6 , national culture variables were added to predicting national corruption after national wealth was controlled for. In contrast to Model 5 , the multiple- $R_{a d j}$ value in Model 6 increased from $R_{a d j}=.85$ to $R_{a d j}=.89$. when national culture variables were added. However, the effect of Individualism is strongly diminished after national wealth is controlled for. This suggests that the effects of national culture on national corruption are partially mediated by national wealth, though culture likely has some independent effect on corruption as well. 
Table 3. Regression models of Combinations of Personality and Culture in Predicting National Corruption

\begin{tabular}{|c|c|c|c|c|c|c|c|c|c|c|c|c|}
\hline \multirow[b]{2}{*}{ Variable } & \multicolumn{3}{|c|}{$\begin{array}{l}\text { Model 1: } \\
\text { Personality }\end{array}$} & \multicolumn{3}{|c|}{$\begin{array}{l}\text { Model 2: } \\
\text { Culture }\end{array}$} & \multicolumn{3}{|c|}{$\begin{array}{c}\text { Model 3: } \\
\text { Personality, Culture }\end{array}$} & \multicolumn{3}{|c|}{$\begin{array}{l}\text { Model 4: } \\
\text { Culture, Personality }\end{array}$} \\
\hline & $R_{a d j}$ & $\square R_{a d j}$ & $\square$ & $R_{a d j}$ & $\square R_{a d j}$ & $\square$ & $R_{a d j}$ & $\square R_{a d j}$ & $\square$ & $R_{a d j}$ & $\square R_{a d j}$ & $\square$ \\
\hline Step 1: & .50 & -- & & .78 & -- & & .64 & - & & .60 & -- & \\
\hline Personality & & & & & & & & & & & & \\
\hline Extraversion & & & .07 & & & & & & -.30 & & & \\
\hline Psychoticism & & & .23 & & & & & & .40 & & & \\
\hline Neuroticism & & & .04 & & & & & & .21 & & & \\
\hline Lie Scale & & & .61 & & & & & & .78 & & & \\
\hline Culture & & & & & & & & & & & & \\
\hline Individ. & & & & & & -.44 & & & & & & -.11 \\
\hline Masc. & & & & & & .16 & & & & & & -.26 \\
\hline Power Dist. & & & & & & .35 & & & & & & .40 \\
\hline Unc. Avoid & & & & & & .17 & & & & & & .45 \\
\hline Step 2: & & & & & & & .69 & .05 & & .69 & .09 & \\
\hline Personality & & & & & & & & & & & & \\
\hline Extraversion & & & & & & & & & -.59 & & & -.59 \\
\hline Psychoticism & & & & & & & & & .68 & & & .68 \\
\hline Neuroticism & & & & & & & & & .21 & & & .21 \\
\hline Lie Scale & & & & & & & & & 1.11 & & & 1.11 \\
\hline Culture & & & & & & & & & & & & \\
\hline Individ. & & & & & & & & & .06 & & & .06 \\
\hline Masc. & & & & & & & & & .11 & & & .11 \\
\hline Power Dist. & & & & & & & & & -.34 & & & -.34 \\
\hline Unc. Avoid & & & & & & & & & -.39 & & & -.39 \\
\hline
\end{tabular}

Note. Boldfaced numbers indicate values for which the $90 \%$ confidence interval does not include zero. $N=36$ for Model 1; $N=50$ for Model 2; $N=15$ for Models 3 and 4. Given the very low sample size for Models 3 and 4 , extreme caution is warranted in interpreting the associated $\square$ coefficients.

Table 4. Regression models of Personality and Culture in Predicting National Corruption, Controlling for National Wealth

\begin{tabular}{|c|c|c|c|c|c|c|}
\hline \multirow[b]{2}{*}{ Variable } & \multicolumn{3}{|c|}{ Model 5: Wealth, Personality } & \multicolumn{3}{|c|}{ Model 6: Wealth, Culture } \\
\hline & $R_{a d j}$ & $\square R_{a d j}$ & $\square$ & $R_{\text {adj }}$ & $\square R_{a d j}$ & $\square$ \\
\hline Step 1: & .88 & - & & .85 & -- & \\
\hline Wealth & & & -.88 & & & -.85 \\
\hline Step 2: & .85 & -.03 & & .89 & .04 & \\
\hline Wealth & & & -.86 & & & \\
\hline \multicolumn{7}{|l|}{ Personality } \\
\hline Extraversion & & & .07 & & & \\
\hline Psychoticism & & & .03 & & & \\
\hline Neuroticism & & & .05 & & & \\
\hline Lie Scale & & & .03 & & & \\
\hline \multicolumn{7}{|l|}{ Culture } \\
\hline Individ. & & & & & & -.10 \\
\hline Masc. & & & & & & .19 \\
\hline Power Dist. & & & & & & .17 \\
\hline Unc. Avoid & & & & & & .15 \\
\hline
\end{tabular}

Note. Boldfaced numbers indicate values for which the $90 \%$ confidence interval does not cross zero. $N=36$ for Model $1 ; N=50$ for Model 2 


\section{Discussion}

The purpose of this paper was to expand existing understanding of the correlates of national corruption to incorporate psychological variables. Past research has focused almost exclusively on describing economic and political antecedents to national corruption, with little theoretical or empirical attention paid to the influence of psychological variables on a nation's level of corruption. However, the results described above show that psychological variables-specifically, national personality and national culture-are strongly related to a nation's level of corruption.

Of the personality variables, psychoticism was consistently related to corruption, such that countries with higher mean levels of psychoticism also were higher in corruption. This finding is consistent with studies of psychoticism-related traits (conscientiousness, agreeableness, and integrity) at the individual level, which has shown these traits to be related to employee counterproductivity (Ones, Viswesvaran, \& Schmidt, 1993; Salgado, 2002) and white collar crime (Collins \& Schmidt, 1993). Therefore, the cause of this correlation between national level psychoticism and national level corruption may be because some nations possess individuals who are more likely to commit such acts. These nations may also have less success establishing and implementing laws, regulations, and punitive measures for such corrupt acts. Alternatively, the causal direction may point the other way: it may be that corruption within a country causes individuals to develop more psychotic personalities. In a country in which corruption is common and less strongly punished, psychotic behavior may be not only more common but also adaptive. That is, abiding by rules and laws in a society in which they are rarely followed may make an individual more vulnerable. Future research should delve more closely into understanding the nature of this relationship.

In addition, national mean scores on a measure of social desirability were strongly predictive of national corruption. This finding is particularly interesting, given that there has been considerable debate in the research literature as to what these scores actually mean at the individual level. The classic perspective has been that these scores are useful for identifying individuals who have in some way inflated their responses to personality items to present themselves in an overly positive way. From this perspective, individuals who score highly on a social desirability scale are being somewhat dishonest and deceitful in completing the personality measure. Interpreting our results from this perspective would suggest that nations whose inhabitants are deceitful and dishonest in completing a personality measure also tend to have inhabitants who are deceitful and dishonest in their professional behavior. Another perspective on social desirability scales is that these scales do not successfully flag dishonest responding at all but instead reflect aspects of several personality traits (specifically, conscientiousness and emotional stability; McCrae \& Costa, 1983). Thus, it may be that national mean scores on a conglomerate of personality traits measured by social desirability scores is strongly related to national corruption. Future research on social desirability scales at both the national and individual level should seek to clarify the meaning of these relationships.

In addition, several cultural variables were predictive of national corruption. Individualism was most strongly related to national corruption, though this relationship was largely diminished once wealth was statistically controlled. However, nations that were high in power distance and uncertainty avoidance were consistently higher in national corruption throughout our analyses. This may be because individuals in nations high in power distance may be less likely to blow the whistle on their corrupt superiors. In such environments, individuals may be more willing or likely to commit corrupt acts. Similarly, individuals in countries high in uncertainty avoidance may engage in more corrupt acts as a means of securing necessary outcomes (e.g., embezzling money to ensure financial solvency; Hofstede, 2001). Alternatively, the causal direction may point the other way: high amounts of corruption within a country mean that individuals' welfare is less secure, which would make forms of uncertainty more threatening. Thus, in addition to scrutinizing national personality, future research should also continue to scrutinize the impact that national culture may have on corruption.

Our analyses also examined aspects of an on-going debate as to whether national personality or national corruption is more central within a culture (Hofstede \& McCrae, 2004). Aspects of our results speak to both 
sides of this debate. National culture was a much stronger predictor of corruption than was national personality, and national culture had unique contributions to predicting national corruption above national wealth. However, national personality provided a greater increment above national culture in predicting national corruption, suggesting that national personality may make more unique contributions to the prediction of corruption. Thus, our findings point to the need for further research as these complimentary and competing perspectives continue to evolve.

The findings presented here have implications for a wide variety of areas of research and application. First, for individuals working closely with national corruption (e.g., researchers and international investors and politicians), this paper highlights a need for greater attention to incorporating national-level psychological variables into studying national corruption. In particular, national culture had considerable impact on corruption above and beyond national wealth. These national-level psychological variables may have an impact on corruption that cannot be accounted for by the customary economic and political indicators. Clearly, future research is needed to expand the available national-level psychological data, both in terms of the number of countries for which such data is available and the number of nationa-level psychological indicators available.

In addition, these national-level findings may have implications for organizations, as well. Organizations continually use personality measures to select individuals who will make their organization a strong performer that is free from corruption, and organizations also attempt to foster an organizational culture that advances the same goals. Yet, most research conducted in this area has focused on individual-level relationships, with comparisons across organizations on organizational variables being terribly rare. Given that such data is terribly difficult to obtain, our results here may shed some light on the effects of personality on counterproductivity in the aggregate. In other words, what makes for corrupt nations may also make for corrupt organizations. This is clearly an area in need of future research, yet our results here may offer a preliminary understanding of aggregate processes of personality.

In discussing the findings and their implications here, several limitations of this study should be born in mind. First, the samples included in our database are not a random sampling of the world's nations. Specifically, Europe and North America are likely overrepresented, whereas Africa, South America, Asia, and the Middle East are likely underrepresented. Furthermore, our sample may be more culturally homogenous than the remainder of the world (e.g., only cultures accepting of psychological testing are represented here). However, if this is the case, this would likely create range restriction on our predictor variables, making our analyses here a conservative test of the relationships between corruption and national personality and culture. As more data becomes available with the globalization of psychological testing, this will allow for more representative sampling of nations.

In addition, our measure of corruption, the Corruption Perceptions Index, is based entirely on individuals' perceptions of corruption in a country. Although the CPI samples from a large base of different individuals and therefore incorporates many different though agreeing perspectives, it is possible that these perceptions do not validly reflect the actual amount of corruption in a country. In a recent Science article, Terracciano et al. (2005) showed that nationallevel stereotypes do not accurately reflect the national personality of a country, and it is possible that the same national misperception affects the CPI. However, in contrast to this research, the CPI surveys generally incorporate individuals who are either experts in corruption or who are likely to have some firsthand knowledge of corrupt behavior. Nonetheless, future research should reexamine this question using an alternate index of national corruption that is not based on perceptions.

The present study has provided a more detailed examination of the effect of national personality on corruption and has made a strong case for considering the effects that national psychological variables may have on the corruption of an entire nation. As research continues to emerge that allow for a more complete understanding of the mechanisms through which these psychological variables function, improved interventions may be designed to alleviate the corruption within corrupted countries. Given the terrible consequences associated with national corruption, this topic merits further scrutiny from all relevant fields. 


\section{References}

Akindele, S. T. (1995). Corruption: An analytical focus on the problems of its conceptualisation. IFE Psychologia: An International Journal, 3, 55-69.

Baehr, M. E., Jones, J. W., \& Nerad, A. J. (1993). Psychological correlates of business ethics orientation in executives. Journal of Business \& Psychology, 7, 291-308.

Barrett, P., \& Eysenck, S. B. G. (1984). The assessment of personality factors across 25 countries. Personality and Individual Differences, 5, 615-632.

Barrett, P. T., Petrides, K. V., Eysenck, S. B. G., \& Eysenck, H. J. (1998). The Eysenck Personality Questionnaire: An examination of the factorial similarity of $\mathrm{P}, \mathrm{E}, \mathrm{N}$, and $\mathrm{L}$ across 34 countries. Personality and Individual Differences, 25, 805-819.

Berry, C. M., Ones, D. S., \& Sackett, P. R. (2005). A Critical Review and Meta-analysis of the Relationships Between Interpersonal Deviance, Organizational Deviance, and Their Common Correlates. Unpublished manuscript.

Bouchard, T. J., \& Loehlin, J. C. (2001). Genes, evolution, and personality. Behavior Genetics, 31, 243-273.

Cohen, J., West, S. G., Aiken, L., \& Cohen, P. (2002). Applied Multiple Regression/Correlation Analysis for the Behavioral Sciences Mahwah, NJ: Lawrence Erlbaum.

Collins, J. M., \& Schmidt, F. L. (1993). Personality, integrity, and white collar crime: A construct validity study. Personnel Psychology, 46, 295-311.

Costa, P. T., Jr., \& McCrae, R. R. (1992). Revised NEO Personality Inventory (NEO-PI-R) and NEO Five Factor Inventory (NEO-FFI) professional manual. Odessa, FL: Psychological Assessment Resources.

Digman, J. M. (1990). Personality structure: Emergence of the Five-Factor Model. Annual Review of Psychology, 41, 417-440.

Digman, J. M. (1997). Higher-order factors of the Big Five. Journal of Personality and Social Psychology, 73, 1246-1256.

Dollar, D., Fisman, S., \& Gatti, R. (2001). Are women really the "fairer" sex? Corruption and women in government. Journal of Economic Behavior \& Organization, 46, 423-429.
Eysenck, H. (1991). The Eysenck Personality Questionnaire-Revised. Sevenoaks: Hodder and Stoughton.

Eysenck, H. J. (1970). The Structure of Human Personality. London: Methuen \& Co.

Goldsmith, A. A. (1999). Slapping the grasping hand: Correlates of corruption in global markets. American Journal of Economics and Sociology, 58, 865-883.

Habib, M., \& Zurawicki, L. (2002). Corruption and foreign direct investment. Journal of International Business Studies, 33, 291-307.

Hofstede, G. S. (1980). Culture's Consequences. Thousand Oaks, CA: Sage.

Hofstede, G. S. (2001). Culture's Consequences. Thousand Oaks, CA: Sage.

Hofstede, G. S., \& McCrae, R. R. (2004). Personality and culture revisited: Linking traits and dimensions of culture. CrossCultural Research: The Journal of Comparative Social Science, 38, 52-88.

Husted, B. (1999). Wealth, culture, and corruption. Journal of International Business Studies, 30, 339-359.

Jackson, D. N., Paunonen, S. V., Fraboni, M., \& Goffin, R. D. (1996). A five-factor versus sixfactor model of personality structure. Personality and Individual Differences, 20, 33-45.

Jackson, H. L. (2006). Ethical Misconduct of Senior Leaders: Counterproductive Work Behaviors at the Top. University of Minnesota, Minneapolis, MN.

Jain, A. K. (2001). Corruption: A review. Journal of Economic Surveys, 15, 71-121.

Johnson, S., Kaufmann, D., \& Zoido-Lobaton, P. (1998). Regulatory discretion and the unofficial economy. American Economic Review, 88, 387-392.

Judge, T. A., Locke, E. A., Durham, C. C., \& Kluger, A. N. (1998). Dispositional effects on job and life satisfaction: The role of core evaluations. Journal of Applied Psychology, 83, 17-34.

Klein, K. J., Bliese, P. D., Kozlowski, S. W. J., Dansereau, F., Gavin, M. B., Griffin, M. A., et al. (2000). Multilevel analytical techniques: Commonalities, differences, and continuing questions. Multilevel theory, research, and methods in organizations, 51, 512-553.

Klein, K. J., Dansereau, F., \& Hall, R. J. (1994). Levels issues in theory development, data 
collection, and analysis. Academy of Management Review, 19, 195-229.

Lambsdorff, J. G. (1995/2004). Background paper to the Corruption Perceptions Index: Transparency International and the University of Passau

Lynn, R., \& Martin, T. (1995). National differences for thirty-seven nations in extraversion, neuroticism, psychoticism and economic, demographic and other correlates. Personality and Individual Differences, 19, 403-406.

Lynn, R., \& Martin, T. (1997). Gender differences in extraversion, neuroticism, and psychoticism in 37 nations. Journal of Social Psychology, 137, 369-373.

McCrae, R. R. (2001). Trait psychology and culture: Exploring intercultural comparisons. Journal of Personality, 69, 819-846.

McCrae, R. R., \& Costa, P. T. (1983). Social desirability scales: More substance than style. Journal of Consulting and Clinical Psychology, 51, 882-888.

Miceli, M. P., van Scotter, J. R., Near, J. P., \& Rehg, M. T. L. E. A. (2001). Responses to perceived organizational wrongdoing: Do perceiver characteristics matter? In J. M. Darley, D. M. Messick \& e. al (Eds.), Social influences on ethical behavior in organizations (pp. 119-135). Mahwah, NJ: Lawrence Erlbaum.
Ones, D. S., Viswesvaran, C., \& Schmidt, F. L. (1993). Comprehensive meta-analysis of integrity test validities findings and implications for personnel selection and theories of job performance. Journal of Applied Psychology, 78, 679-703.

Salgado, J. (2002). The Big Five personality dimensions and counterproductive behaviors. International Journal of Selection \& Assessment, 10, 117-125.

Steel, P., \& Ones, D. S. (2002). Personality and happiness: A national-level analysis. Journal of Personality \& Social Psychology, 83, 767781.

Swamy, A., Knack, S., Lee, Y., \& Azfar, O. (2001). Gender and Corruption. Journal of Development Economics, 64, 25-55.

Terracciano, A., Abdel-Khalek, A. M., Adam, N., Adamovova, L., Ahn, C., Ahn, H. N., et al. (2005). National character does not reflect mean personality trait levels in 49 cultures. Science, 310, 96-100.

van Hemert, D. A., van de Vijver, F. J. R., Poortinga, Y. H., \& Georgas, J. (2002). Structural and functional equivalence of the Eysenck Personality Questionnaire within and between countries. Personality \& Individual Differences, 33, 1229-1249.

Xin, X., \& Rudel, T. K. (2004). The context for political corruption: A cross-national analysis. Social Science Quarterly, 85, 294-309.

\section{Appendix}

Characteristics of surveys incorporated in the 1995-2004 Corruption Perceptions Index

\begin{tabular}{|c|c|c|c|c|c|c|}
\hline Organization & Source & $\begin{array}{c}\text { Years } \\
\text { administered }\end{array}$ & $\begin{array}{c}\text { Yearly } \\
\text { Sample/Size }\end{array}$ & $\begin{array}{c}\text { \# of } \\
\text { Countries }\end{array}$ & Subject & $\begin{array}{l}\text { Years } \\
\text { in CPI }\end{array}$ \\
\hline $\begin{array}{l}\text { Business } \\
\text { International }\end{array}$ & & 1980 & $\begin{array}{l}\text { Staff of } \\
\text { journalists }\end{array}$ & 68 & $\begin{array}{l}\text { Degree to which } \\
\text { transactions involve } \\
\text { corruption or } \\
\text { questionable payments }\end{array}$ & $1995-6$ \\
\hline $\begin{array}{l}\text { Columbia } \\
\text { University }\end{array}$ & $\begin{array}{l}\text { State Capacity } \\
\text { Survey }\end{array}$ & 2001-2003 & $\begin{array}{l}224-251 \\
\text { country } \\
\text { experts (US) }\end{array}$ & $95-121$ & $\begin{array}{l}\text { Severity of corruption } \\
\text { within the state }\end{array}$ & $2002-4$ \\
\hline DRI/McGraw-Hill & $\begin{array}{l}\text { Global Risk } \\
\text { Service }\end{array}$ & 1997 & Expert staff & 106 & $\begin{array}{l}\text { Losses and costs due to } \\
\text { corruption }\end{array}$ & 1997 \\
\hline $\begin{array}{l}\text { Economist } \\
\text { Intelligence Unit }\end{array}$ & $\begin{array}{l}\text { Country Risk } \\
\text { Service and } \\
\text { Country Forecast }\end{array}$ & 1998-2004 & $\begin{array}{l}\text { Expert staff } \\
\text { (expatriates) }\end{array}$ & $115-142$ & $\begin{array}{l}\text { The misuse of public } \\
\text { office for private gain }\end{array}$ & $\begin{array}{l}1998- \\
2004\end{array}$ \\
\hline
\end{tabular}




\begin{tabular}{|c|c|c|c|c|c|c|}
\hline Freedom House & Nations in Transit & $\begin{array}{r}1998,2000- \\
2004\end{array}$ & $\begin{array}{l}\text { Experts (US, } \\
\text { regional, and } \\
\text { in-country } \\
\text { experts) }\end{array}$ & $27 / 28$ & $\begin{array}{l}\text { Extent of corruption as } \\
\text { practiced in } \\
\text { governments, as } \\
\text { perceived by the public } \\
\text { and as reported in the } \\
\text { media as well as the } \\
\text { implementation of } \\
\text { anticorruption initiatives. }\end{array}$ & $\begin{array}{l}1999- \\
2004\end{array}$ \\
\hline Gallup & $\begin{array}{l}\text { 50th Anniversary } \\
\text { Survey }\end{array}$ & 1997 & $\begin{array}{l}34000 \text { in the } \\
\text { general } \\
\text { public }\end{array}$ & 44 & $\begin{array}{l}\text { A lot, many, few or no } \\
\text { cases of corruption for } \\
\text { politicians, public } \\
\text { officials, policemen, and } \\
\text { judges. }\end{array}$ & $1997-9$ \\
\hline $\begin{array}{l}\text { Gallup } \\
\text { International/Trans } \\
\text { parency } \\
\text { International }\end{array}$ & $\begin{array}{l}\text { Corruption } \\
\text { Survey }\end{array}$ & 2002 & $\begin{array}{l}835 \text { Senior } \\
\text { business } \\
\text { people }\end{array}$ & 21 & $\begin{array}{l}\text { How common are bribes } \\
\text { to politicians, senior civil } \\
\text { servants, and judges and } \\
\text { how significant of an } \\
\text { obstacle are the costs } \\
\text { associated with such } \\
\text { payments for doing } \\
\text { business? }\end{array}$ & $2002-4$ \\
\hline $\begin{array}{l}\text { Goettingen } \\
\text { University }\end{array}$ & $\begin{array}{l}\text { Internet } \\
\text { Corruption } \\
\text { Perception Index }\end{array}$ & 1997 & $\begin{array}{l}246 \text { Internet } \\
\text { users }\end{array}$ & 71 & $\begin{array}{l}\text { Are public officials often, } \\
\text { sometimes, or rarely } \\
\text { asking for bribes }\end{array}$ & 1997 \\
\hline $\begin{array}{l}\text { Information } \\
\text { International }\end{array}$ & $\begin{array}{l}\text { Survey of Middle } \\
\text { Eastern } \\
\text { Businesspeople }\end{array}$ & 2003 & $\begin{array}{l}165 \text { Senior } \\
\text { businesspeo } \\
\text { ple from } \\
\text { Bahrain, } \\
\text { Lebanon and } \\
\text { UAE }\end{array}$ & 31 & $\begin{array}{l}\text { How common are bribes, } \\
\text { how costly are they for } \\
\text { doing business and how } \\
\text { frequently are public } \\
\text { contracts awarded to } \\
\text { friends and relatives in } \\
\text { neighboring countries }\end{array}$ & $2003-4$ \\
\hline $\begin{array}{l}\text { International } \\
\text { Institute for } \\
\text { Management } \\
\text { Development }\end{array}$ & $\begin{array}{l}\text { World } \\
\text { Competitiveness } \\
\text { Yearbook }\end{array}$ & $\begin{array}{l}1992-1994 \\
1996-2004\end{array}$ & $\begin{array}{l}2515-4166 \\
\text { Executives } \\
\text { in top and } \\
\text { middle } \\
\text { management } \\
\text {; domestic } \\
\text { and } \\
\text { international } \\
\text { companies }\end{array}$ & $46-51$ & $\begin{array}{l}\text { Bribing and corruption } \\
\text { exist in the public } \\
\text { sphere/economy }\end{array}$ & $\begin{array}{l}1995- \\
2004\end{array}$ \\
\hline $\begin{array}{l}\text { International } \\
\text { Working Group }\end{array}$ & $\begin{array}{l}\text { International } \\
\text { Crime Victim } \\
\text { Survey }\end{array}$ & 1997,2000 & $\begin{array}{l}20,000- \\
40,000 \text { in the } \\
\text { general } \\
\text { public }\end{array}$ & 11 & $\begin{array}{l}\text { During } 1995 \text {, has any } \\
\text { government official, for } \\
\text { instance a customs } \\
\text { officer, police officer, or } \\
\text { inspector in your own } \\
\text { country, asked or } \\
\text { expected you to pay a } \\
\text { bribe for his services }\end{array}$ & $\begin{array}{l}1999 \\
2000\end{array}$ \\
\hline $\begin{array}{l}\text { Merchant } \\
\text { International } \\
\text { Group }\end{array}$ & $\begin{array}{l}\text { Grey Area } \\
\text { Dynamics }\end{array}$ & 2004 & $\begin{array}{l}\text { Expert staff } \\
\text { and network } \\
\text { of local } \\
\text { corresponde } \\
\text { nts }\end{array}$ & 155 & $\begin{array}{l}\text { Corruption, ranging from } \\
\text { bribery of government } \\
\text { ministers to inducements } \\
\text { payable to the "humblest } \\
\text { clerk." }\end{array}$ & 2004 \\
\hline
\end{tabular}




\begin{tabular}{|c|c|c|c|c|c|c|}
\hline \multirow[t]{2}{*}{$\begin{array}{l}\text { Political \& } \\
\text { Economic Risk } \\
\text { Consultancy }\end{array}$} & $\begin{array}{l}\text { Asian Intelligence } \\
\text { Newsletter }\end{array}$ & $1997-2004$ & $\begin{array}{l}280->1000 \\
\text { Expatriate } \\
\text { business } \\
\text { execs. }\end{array}$ & 12,14 & $\begin{array}{l}\text { How bad do you consider } \\
\text { the problem of corruption } \\
\text { to be in the country in } \\
\text { which you are working as } \\
\text { well as in your home } \\
\text { country? }\end{array}$ & $\begin{array}{l}1997- \\
2004\end{array}$ \\
\hline & $\begin{array}{l}\text { Bank Executives } \\
\text { Survey }\end{array}$ & $1992-1994$ & $\begin{array}{l}60 \text { senior } \\
\text { executives of } \\
\text { banks }\end{array}$ & 10 & Levels of corruption & $1995-6$ \\
\hline \multirow[t]{2}{*}{$\begin{array}{l}\text { Political Risk } \\
\text { Service }\end{array}$} & $\begin{array}{l}\text { Expert staff } \\
\text { Survey }\end{array}$ & 1988,1998 & Expert staff & 128 & $\begin{array}{l}\text { Likeliness to demand } \\
\text { special and illegal } \\
\text { payments in high and low } \\
\text { levels of government }\end{array}$ & $\begin{array}{l}1996 \\
1998\end{array}$ \\
\hline & $\begin{array}{l}\text { International } \\
\text { Country Risk } \\
\text { Guide }\end{array}$ & 2000 & Expert staff & 140 & $\begin{array}{l}\text { Assessment of } \\
\text { "corruption in } \\
\text { government" }\end{array}$ & $\begin{array}{l}1999- \\
2000\end{array}$ \\
\hline $\begin{array}{l}\text { PriceWaterhouse } \\
\text { Coopers }\end{array}$ & Opacity Index & 2001 & $\begin{array}{l}1,357 \text { CFOs, } \\
\text { equity } \\
\text { analysts, } \\
\text { bankers and } \\
\text { PwC staff }\end{array}$ & 34 & $\begin{array}{l}\text { Frequency of corruption } \\
\text { in various contexts (e.g. } \\
\text { obtaining import/export } \\
\text { permits or subsidies, } \\
\text { avoiding taxes) }\end{array}$ & $2000-3$ \\
\hline Unnamed & $\begin{array}{l}\text { A Multilateral } \\
\text { Development } \\
\text { Bank Survey }\end{array}$ & 2002 & $\begin{array}{l}398 \text { Experts } \\
\text { within the } \\
\text { bank }\end{array}$ & 47 & $\begin{array}{l}\text { How widespread is the } \\
\text { incidence of corruption? }\end{array}$ & $2003-4$ \\
\hline $\begin{array}{l}\text { Wall Street } \\
\text { Journal, Central } \\
\text { European } \\
\text { Economic Review }\end{array}$ & Annual Survey & 1997 & $\begin{array}{l}\text { Business } \\
\text { analysts in } \\
\text { Europe and } \\
\text { US }\end{array}$ & 26 & $\begin{array}{l}\text { Effect of corruption on } \\
\text { attractiveness of country } \\
\text { as a place to do business }\end{array}$ & 1999 \\
\hline \multirow[t]{2}{*}{ World Bank } & $\begin{array}{l}\text { World Business } \\
\text { Environment } \\
\text { Survey }\end{array}$ & 2001 & $\begin{array}{l}10,900 \\
\text { Senior } \\
\text { managers }\end{array}$ & 79 & $\begin{array}{l}\text { Frequency of bribing and } \\
\text { "corruption as a } \\
\text { constraint to business" }\end{array}$ & $2000-3$ \\
\hline & $\begin{array}{l}\text { World } \\
\text { Development } \\
\text { Report, Private } \\
\text { Sector Survey }\end{array}$ & 1997 & $\begin{array}{l}3500 \\
\text { Business } \\
\text { executives }\end{array}$ & 73 & $\begin{array}{l}\text { Irregular, additional } \\
\text { payments are common } \\
\text { and represent an } \\
\text { obstacle to doing } \\
\text { business }\end{array}$ & $1998-9$ \\
\hline World Bank/ERBD & $\begin{array}{l}\text { Business } \\
\text { Environment \& } \\
\text { Enterprise } \\
\text { Performance } \\
\text { Survey (BEEPS) }\end{array}$ & 1999, 2002 & $\begin{array}{l}3000 / 6500 \\
\text { senior } \\
\text { business } \\
\text { people }\end{array}$ & $20 / 25$ & $\begin{array}{l}\text { Frequency of irregular } \\
\text { additional payments; how } \\
\text { problematic is corruption } \\
\text { for business? }\end{array}$ & $\begin{array}{l}2000 \\
2003-4\end{array}$ \\
\hline \multirow[t]{2}{*}{$\begin{array}{l}\text { World Economic } \\
\text { Forum }\end{array}$} & $\begin{array}{l}\text { Global } \\
\text { Competitveness } \\
\text { Report }\end{array}$ & $1996-2004$ & $\begin{array}{l}1537-8700 \\
\text { Senior } \\
\text { business } \\
\text { leaders }\end{array}$ & $40-104$ & $\begin{array}{l}\text { Undocumented extra } \\
\text { payments connected with } \\
\text { various government } \\
\text { functions. }\end{array}$ & $\begin{array}{l}1998- \\
2004\end{array}$ \\
\hline & $\begin{array}{l}\text { Africa } \\
\text { Competitiveness } \\
\text { Report }\end{array}$ & 1998,2000 & $\begin{array}{l}582 / 1,800 \\
\text { senior } \\
\text { business } \\
\text { leaders }\end{array}$ & 20,26 & $\begin{array}{l}\text { How problematic is } \\
\text { corruption? Are irregular, } \\
\text { additional payments } \\
\text { required? In large } \\
\text { amounts? }\end{array}$ & $\begin{array}{l}1999- \\
2002\end{array}$ \\
\hline $\begin{array}{l}\text { World Markets } \\
\text { Research Center }\end{array}$ & Risk Ratings & 2002,2004 & Expert staff & 186 & $\begin{array}{l}\text { The likelihood of } \\
\text { encountering corrupt } \\
\text { officials, ranging from } \\
\text { petty bureaucratic } \\
\text { corruption to grand } \\
\text { political corruption. }\end{array}$ & $2003-4$ \\
\hline
\end{tabular}

